Matea Kovač*

Davor Filipović **

Najla Podrug ${ }^{* * *}$
JEL Classification M10, M16

Pregledni rad

https://doi.org/10.32910/ep.70.3.9

\title{
PARTIKULARNOSTI STRATEŠKOG UPRAVLJANJA MEĐUNARODNIM PODRUŽNICAMA
}

Kako međunarodno poduzeće čini grupa geografski disperziranih međunarodnih podružnica od kojih svaka ima svoje vlastite ciljeve $i$ želje vezane uz razvoj, logičnim se nameće potreba za izučavanjem partikularnosti u strateškom upravljanju međunarodnim podružnicama. U radu je prikazana konceptualizacija i evolucija međunarodnih poduzeća i međunarodnih podružnica. Zasebno su analizirane vrste uloga međunarodnih podružnica. Literatura potvrđuje kako međunarodne podružnice imaju određene uloge koje obnašaju unutar međunarodnog poduzeća, a interakcija između matičnog poduzeća i međunarodnih podružnica i utjecaj lokalnog tržišta na poslovanje međunarodnih podružnica su krucijalni u definiranju uloga i odgovornosti. Od svih identificiranih varijabli, integriranost i autonomija su značajno prisutne u gotovo svim vrstama uloga. Upravljanje međunarodnim podružnicama uključuje i razvoj međunarodnih podružnica koji može biti promatran prema matičnom poduzeću, ali i u zemlji u kojoj se nalazi me-

* Dr. sc. M. Kovač, Ericsson Nikola Tesla d.d., Zagreb (E-mail: mateakovac@gmail.com).

${ }^{* *}$ Dr. sc. D. Filipović, docent, Sveučilište u Zagrebu, Ekonomski fakultet (E-mail: dfilipovic@ efzg.hr).

${ }^{* * *}$ Dr. sc. N. Podrug, izvanredna profesorica, Sveučilište u Zagrebu, Ekonomski fakultet (Email: npodrug@efzg.hr).

Rad se temelji na istraživanju doktorske disertacije obranjene u akademskoj godini 2017./2018. te je prilagođen objavi u časopisu kako bi se rezultati istraživanja stavili na raspolaganje široj znanstvenoj i stručnoj javnosti.

Rad je primljen u uredništvo 14.03.2018. godine, a prihvaćen je za objavu 25.06.2018. godine. 
đunarodna podružnica. U zaključku rada su također istaknute specifičnosti odnosa matičnog poduzeća i međunarodnih podružnica kao relevantan dio strateškog upravljanja međunarodnim podružnicama.

Ključne riječi: međunarodno poduzeće, matično poduzeće, međunarodna podružnica, strateško upravljanje

\section{Uvod}

Međunarodno poduzeće u praksi najčešće čini matično poduzeće te s njim povezana poduzeća koja su u većinskom ili potpunom vlasništvu. Međunarodna podružnica predstavlja koncept polu-autonomnog entiteta s korporativnim potencijalom koja posluje na kompleksnom tržištu, a koje se sastoji od internih i eksternih sudionika. Relativna snaga spomenutog kompleksnog tržišta oblikuje potencijalne opcije za razvoj međunarodne podružnica.

Uloga međunarodnih poduzeća je nemjerljiva jer utječu na alokaciju i korištenje resursa, stvaranje novih proizvoda i usluga, stvaranje novih metoda proizvodnje i distribucije, pojedinačno zapošljavaju stotine tisuća ljudi, ulažu u nove tehnologije i čine većinu međunarodne trgovine. Kako međunarodno poduzeće čini grupa geografski disperziranih međunarodnih podružnica od kojih svaka ima svoje vlastite ciljeve i želje vezane uz razvoj, logičnim se nameće potreba matičnog poduzeća za korištenjem mehanizama s ciljem smanjivanja neizvjesnosti i povećanja kontrole nad ponašanjem međunarodnih podružnica kako bi osigurali provođenje strategije koja donosi najbolje poslovne rezultate za međunarodno poduzeće.

U ovom radu će biti analizirane specifičnosti strateškog upravljanja međunarodnim podružnicama na način da su prvo definirana međunarodna poduzeća, a potom međunarodne podružnice. Konceptualizacija, evolucija i vrste uloga međunarodnih podružnica prikazane u zasebnim poglavljima ovog rada, nakon čega slijedi poglavlje o razvoju međunarodnih podružnica. U zaključku rada su istaknute specifičnosti odnosa matičnog poduzeća i međunarodnih podružnica kao relevantan dio strateškog upravljanja međunarodnim podružnicama.

\section{Konceptualizacija i evolucija međunarodnih poduzeća}

Mnogi autori su pokušali i još uvijek pokušavaju definirati pojam međunarodnog poduzeća. U nastavku su prikazane definicije istaknutih autora, kao i de- 
finicije od strane UN-a i američkog Ureda za ekonomske analize (eng. Bureau of Economic Analysis).

Jednu od prvih definicija međunarodnih poduzeća je formulirao Lilienthal (1960) koji je opisao međunarodno poduzeće kao poduzeće koje ima sjedište u jednoj državi, ali ,živi“ i posluje u drugim državama u skladu sa zakonima i specifičnostima pojedinog područja. Hymer (1960) definira međunarodna poduzeća kao tipično velika poduzeća koja posluju na imperfektno konkurentnim tržištima, a njihova efikasnosti ovisi o efikasnosti oligopolističkog donošenja odluka. Prema Aharoni (1971) postoje 4 vrste definicija koja objašnjavaju pojam međunarodnih poduzeća, redom su to:

1. operativna ili tehnička definicija - međunarodno poduzeće je poduzeće koje posjeduje ili kontrolira dobit nastalu u više zemalja,

2. strukturna definicija međunarodnih poduzeća - obuhvaća više strukturnih kriterija za definiranje međunarodnih poduzeća poput broja zemalja u kojima je prisutno, vlasništva i organizacijske strukture,

3. definicija pomoću poslovnih performansi - međunarodna poduzeća su definirana većim brojem različitih atributa i performansi (npr. broj međunarodnih podružnica, volumen prodaje koja se ostvaruje u inozemstvu, vrijednost inozemne aktive itd.),

4. definicija temeljena na bihevioralnim kriterijima - međunarodna poduzeća su definirana stupnjem geocentričnosti poduzeća.

Možda najjednostavniju definiciju je dao Casson (1982) koji je definirao međunarodno poduzeće kao poduzeće koje posjeduje proizvode ili usluge koji su proizvedeni u više zemalja. Osim definicija danih od strane znanstvenika, UN je početkom 1970-ih godina također definirao međunarodno poduzeće kao „organizaciju koja kontrolira imovinu, tvornice, rudnike, prodajne urede u dvije ili više zemalja“. Desetak godina poslije promijenili su i unaprijedili definiciju, a sve više se počinje rabiti naziv transnacionalne korporacije umjesto pojma multinacionalna korporacija. Nova definicija multinacionalne korporacije odnosno transnacionalne korporacije označuje poduzeća koja (UN, 1985):

a) imaju poslovne entitete u dvije ili više zemalja, nevezano za pravnu formu i područje aktivnosti tih entiteta,

b) imaju sustav odlučivanja koji omogućuje koherentne politike i zajedničke strategije koordinirane iz jednog ili više centara odlučivanja,

c) entiteti su povezani, putem vlasničkih i drugih odnosa, na takav način da jedan ili više entiteta mogu utjecati na aktivnosti drugih entiteta, a posebice pri dijeljenju znanja, resursa i odgovornosti s drugima.

Iz ove UN definicije evidentno je kako je znatno važnija integracija u smislu upravljačkih aktivnosti od potpunog vlasništva nad imovinom. Američki Ured za 
ekonomske analize definira međunarodno poduzeće kao: „svaki (američki) poduzetnički poduhvat koji drži najmanje $10 \%$ vlasništva nad barem jednim stranim poslovnim poduhvatom.“

Birkinshaw (1995) kao jedan od najistaknutijih istraživača na temu međunarodnih poduzeća ističe kako su međunarodna poduzeća velike i geografski raspršene organizacije koje nastoje održati kontrolu nad svojim aktivnostima unatoč činjenici da djeluju na velikim udaljenostima i unutar različitih pravnih okvira.

Autori u području međunarodne ekonomije i trgovine definiraju međunarodna poduzeća kao poduzeća koja imaju vlastite podružnice u jednoj ili više država odnosno poduzeća koja imaju omjer stranih aktivnosti prema ukupnim aktivnostima (npr. prodaja, zaposlenici itd.) veći od nekog proizvoljnog broja, npr. omjer stranih aktivnosti prema ukupnim aktivnostima iznosi 10\% ili 25\% (Rugman, 2006).

Bartlett (2008) naglašava kako nije važan pravni entitet, već je partikularnost međunarodnih poduzeća ,aktivno i koordinirano upravljanje operacijama u različitim zemljama“. Dunning (2010) pak definira međunarodna poduzeća kao „poduzeća koja su uključena u izravna inozemna ulaganja i posjeduju, odnosno na neki način kontroliraju, aktivnosti koje stvaraju dodanu vrijednost u drugim državama.“

Kronološki prikazane definicije međunarodnih poduzeća izabranih autora potvrđuju kompleksnost pojma međunarodnih poduzeća.

Evolucija međunarodnih poduzeća može se promatrati kroz nekoliko faza. Rahimić i Podrug (2013) ih dijele na faze europskih, američkih i japanskih poduzeća, dok su Greer i Singh (2000) identificirali fazu prije 19. stoljeća, fazu između Prvog i Drugog svjetskog rata te fazu nakon Drugog svjetskog rata.

Vezano uz evoluciju međunarodnih poduzeća, važno je istaknuti kako se najraniji oblici međunarodnih poduzeća pronalaze u Zapadnoj Europi i datiraju iz 16. stoljeća. Tada su zapadnoeuropske zemlje širile svoju trgovinu na kolonijalne zemlje u čemu su prednjačile Engleska i Nizozemska (Greer i Singh, 2000). Upravo se prvim modernim međunarodnim poduzećem smatra Dutch East India Company koje je osnovano 1602. godine (Rahimić i Podrug, 2013). Spomenuto međunarodno poduzeće i ona koja su nastala nakon njega (Imperial Chemicals iz Engleske, Siemens iz Njemačke, Saint-Gobain iz Francuske) bila su najvećim dijelom okrenuta iskorištavanju kolonijalnih bogatstava za europske matične države i bile su podjednako sredstvo politike koliko i ekonomije (Braverman, 1983). Zbog činjenice da su europska poduzeća prednjačila u ovoj fazi ona se i naziva fazom europskih poduzeća. Ovdje je bitno napomenuti kako je ta faza obilježena protekcionizmom, otežanim uvjetima transporta, sporom i nepouzdanom komunikacijom te diferenciranim nacionalnim tržištima (Rahimić i Podrug, 2013). Slijedom navedenih obilježja europska poduzeća su se razvila kao decentralizirane federa- 
cije u kojima je matično poduzeće osiguravalo kapitalna ulaganja, dok su međunarodne podružnice bile operativno autonomne i mogle su modificirati proizvodne i marketinške aktivnosti kako bi zadovoljile vrlo različite lokalne tržišne potrebe. Autonomiji međunarodnih podružnica su dodatno pridonijele brojne teškoće u transportu i komunikaciji, što je sprječavalo menadžment matičnog poduzeća da intervenira u aktivnosti međunarodnih podružnica diljem svijeta pa su tako europska poduzeća udvostručavala troškove svojih aktivnosti jer nisu efikasno koordinirala prekogranična djelovanja. Na taj način se postizala lokalna odgovornost na štetu globalne integracije (Rahimić i Podrug, 2013). Ovo razdoblje karakterizira i početak ,velikog vala“ spajanja i preuzimanja poduzeća u Americi. Posljedica spomenutih spajanja i preuzimanja je nestanak više od 1.800 poduzeća, a glavni motiv spajanja i preuzimanja bio je kreiranje monopola (Filipović, 2012).

Razdoblje između Prvog i Drugog svjetskog rata je obilježilo porast potražnje za prirodnim resursima što je djelovalo kao svojevrsni poticaj europskim i američkim poduzećima prema inozemnim ulaganjima. U tom razdoblju su europska inozemna ulaganja opala zbog ratnih posljedica, dok su s druge strane američka poduzeća doživjela snažnu ekspanziju (Greer i Singh, 2000). U tom razdoblju, točnije 1920. počinje drugi val spajanja i preuzimanja poduzeća koji traje do 1929. slomom tržišta kapitala uzrokovanog globalnom depresijom (Filipović, 2012). Nakon Drugog svjetskog rata izražena je dominacija američkih poduzeća zahvaljujući tehnološkoj superiornosti pa se ta faza naziva fazom američkih poduzeća. Faza američkih poduzeća se odnosi na razdoblje 1950.-ih i 1960.-ih godina (Rahimić i Podrug, 2013). Tehnološka superiornost se odnosila na napredak u prekomorskom transportu, zračnom transportu i komunikaciji što je ubrzalo inozemna ulaganja američkih poduzeća jer su im superiorne tehnološke sposobnosti omogućile tržišnu ekspanziju (Greer i Singh, 2000). Američka su se poduzeća razvijala kao koordinirane federacije koje obilježuju rigidne strukture, centralizirano planiranje te prijenos znanja iz matičnog poduzeća u međunarodne podružnice. Međunarodne podružnice su imale ograničenu autonomiju, ponajprije za modificiranje proizvoda u skladu s lokalnim preferencijama (Rahimić i Podrug, 2013). Krajem 1950.ih godina počinje treći val spajanja i preuzimanja poduzeća koji završava 1973. godine kao posljedica naftne krize (Filipović, 2012). Svi nabrojeni trendovi koji su karakterizirali razdoblje nakon Drugog svjetskog rata pa do početka 1970.-ih godina su činili razliku između poduzeća tog razdoblja i poduzeća prije Drugog svjetskog rata. I dok su prije rata bila vodeća dva ili tri poduzeća s ukupnom vrijednosti imovine 500 milijuna USD, neposredno u godinama nakon rata postajalo je 333 takvih poduzeća, od kojih je trećina posjedovala imovinu u vrijednosti od 1 milijarde USD (Greer i Singh, 2000).

Razdoblje iza 1970. godine obilježavaju japanska poduzeća koja su tad počela s internacionalizacijom. Kako nisu imali prethodnih međunarodnih iskustva, odlučili su se za drukčiji pristup od američkih i europskih konkurenata. Bili su 
svjesni svoje slabosti, a to je bila nemogućnost konkuriranja europskim i američkim poduzećima koja su imala vrlo razvijenu lokalnu proizvodnju i marketinške aktivnosti prilagođene nacionalnim uvjetima. Stoga su se japanska poduzeća fokusirala na efikasnost proizvodnje i iskorištavanje ekonomije obujma. Zatim su iskoristili i znatan pad trgovinskih barijera, pa su se intenzivno širili na svjetskom tržištu. U temeljima internih organizacijskih procesa japanskih poduzeća bitno je spomenuti snažne kulturološke vrijednosti kolektivizma i interpersonalne harmonije (Rahimić i Podrug, 2013). U ovom razdoblju se javlja četvrti val spajanja i preuzimanja poduzeća koji počinje 1981. godine i završava 1987. godine slomom tržišnog kapitala (Filipović, 2012).

Nakon 1990. godine globalizacija i vlasničke integracije snažno utječu na povećanje inozemnih izravnih ulaganja i samim time na širenje međunarodnih poduzeća. Ekspanzija međunarodnih poduzeća u tom razdoblju može se podijeliti na dvije faze (UNCTAD, 2017), faza između 1993. i 1997. godine te između 2003. i 2010. godine. Upravo 2003. godine, potaknut globalizacijom, tehnološkim inovacijama, privatizacijom i snažnim procvatom financijskog tržišta, počeo je peti val spajanja i preuzimanja poduzeća. Završio je 2000. godine slomom tržišta kapitala (Filipović, 2012). U 2003.-oj godini aktivnosti spajanja i preuzimanja ponovno jačaju zbog niskih kamatnih stopa koje su omogućile jeftina zaduživanja. Time počinje šesti val spajanja i preuzimanja poduzeća koji traje do 2008. godine slomom tržišta nekretnina u Americi uzrokovanog svjetskom i gospodarskom krizom. Iako je tada značajno opao broj spajanja i preuzimanja poduzeća, čak 43,30\% u 2009.-oj godini s obzirom na 2007. godine (Filipović, 2012), međunarodna poduzeća su se i dalje širila (UNCTAD, 2017).

\section{Konceptualizacija i evolucija međunarodnih podružnica}

Literatura na temu međunarodnih podružnica je relativno nova jer su autori uglavnom bili orijentirani na međunarodna poduzeća i načine inozemnih izravnih ulaganja, dok se međunarodnim podružnicama veći fokus dao tek nastankom teorije internalizacije. Razvoj literature međunarodnih podružnica je prikazan na slici 1. gdje se u samim počecima razvio koncept međunarodnih podružnica koji je onda vremenom mijenjan ovisno kako su se mijenjali pogledi autora na međunarodno poduzeće. Nakon konceptualizacije, autori su se orijentirali prema definiranju uloga međunarodnih podružnica u ovisnosti o različitim dimenzijama, zatim na razvoj međunarodnih podružnica. Zadnjih dvadeset godina, literatura se uglavnom bavi odnosom između matičnog poduzeća i međunarodnih podružnica koristeći više teorija prilikom objašnjavanja spomenutog fenomena. 
Slika 1.

\section{RAZVOJ LITERATURE O MEĐUNARODNIM PODRUŽNICAMA}

\begin{tabular}{|c|c|c|c|c|}
\hline & & & & Orijentacija na odnos matičnog poduzeća i međunarodnih podružnica \\
\hline \multicolumn{5}{|c|}{ Orijentacija na razvoj međunarodnih podružnica } \\
\hline \multicolumn{5}{|c|}{ Orijentacija na uloge međunarodnih podružnica } \\
\hline \multicolumn{5}{|c|}{ Orijentacija na konceptualizaciju međunarodnih podružnica } \\
\hline 1950. & 1960. & 1970. & 1980. & 1990. \\
\hline
\end{tabular}

Izvor: Paterson, S. L. i Brock, D. M. (2002.), The development of subsidiary-management research: review and theoretical analysis, International Business Review, 11(2): 148.

Koncept međunarodnih podružnica se odnosi na polu-autonoman entitet koji djeluje u izrazito kompleksnom okruženju i ima određeni stupanj autonomije u poslovanju (Birkinshaw, 1995). Kompleksno okruženje podrazumijeva internu i eksternu mrežu međunarodnih podružnica, gdje se unutar interne mreže međunarodne podružnice susreću s kupcima, dobavljačima i drugim međunarodnim podružnicama koji čine dio istog međunarodnog poduzeća, a unutar eksterne mreže se susreću s kupcima, dobavljačima i vanjskom konkurencijom (Birkinshaw, Hood i Young, 2005). Upravo suočavanje s dvije vrste mreža čini međunarodne podružnice jedinstvenim i tjera ih na konstantno balansiranje između lokalne adaptacije i globalne standardizacije (Westney, 1993). Snaga mreža uvelike ima utjecaj na rast i razvoj međunarodnih podružnica oblikujući potencijalne prilike koje međunarodne podružnice mogu iskoristiti i na taj način napredovati (Birkinshaw i Fry, 1998).

Do prije 40-ak godina prevladavali su tradicionalni pogledi na međunarodno poduzeće unutar kojih se smatralo da matično poduzeće razvija vlasničku prednost koju onda transferira u međunarodne podružnice, odnosno međunarodne podružnice su smatrane pasivnim implementatorima strategije matičnog poduzeća (Dunning, 1982). Prve osnovane podružnice su bile u obliku minijaturnih replika s gotovo nikakvom odgovornosti i mogućnosti utjecaja na poslovanje (White i Poynter, 1984), no globalizacija i liberalizacija vanjske trgovine su utjecali na to da međunarodne podružnica preuzmu uloge s malo većim utjecajem na modifikaciju poslovanja, ali još uvijek s prilično suženim granicama odgovornosti (Pearce, 1992). 
Kroz vrijeme su međunarodne podružnice napredovale i razvile vlastite resurse čime je postalo jasno kako matična poduzeća više nisu isključivi izvor konkurentske prednosti međunarodnog poduzeća i u tom razdoblju su razvijeni novi pogledi kao što su heterarhijski (Hedlund, 1986) i transnacionalni pogled (Bartlett i Goshal, 1989) na međunarodno poduzeće. Ti pogledi mijenjaju dosadašnji koncept međunarodnih podružnica i stajališta vezana uz njihov razvoj i uloge (Birkinshaw i Hood, 2016).

U kontekstu koncepta međunarodnih podružnica bitno je spomenuti upravljanje međunarodnih poduzeća jer ga one čine izuzetno kompleksnim (Pahlberg, 1996). Međunarodne podružnice su locirane u različitim državama i samim time se pretpostavlja postojanje razlika između nacionalnih kultura međunarodnih podružnica i matičnog poduzeća (Kogut i Singh, 1988). U državama gdje su locirane, međunarodne podružnice su involvirane u eksternu mrežu i mogu razvijati različite ideje i ciljeve od onih koje se razvijaju u matičnom poduzeću. U isto vrijeme upravo ta dislociranost odnosno geografska raspršenost omogućuje prednost međunarodnih poduzeća nad lokalnim poduzećima s obzirom da međunarodno poduzeće putem svojih međunarodnih podružnica ima direktan pristup različitim izvorima znanja. Zbog svega navedenog međunarodno poduzeće ima potencijal kombiniranja prednosti koje proizlaze iz specifičnosti poduzeća s prednostima koje proizlaze iz specifičnosti lokacija kroz interni transfer resursa (Gupta i Govindarajan, 2000).

Premda su međunarodne podružnice konstantno svjesne dinamike u internoj okolini te se brinu hoće li investicije biti usmjerene prema drugim lokacijama i za njih natječu s ostalim međunarodnim podružnicama, uobičajeno je da među njima ipak postoji visoka razina razmjene informacija i znanja kao i prenošenja najbolje prakse (Birkinshaw, Hood i Young, 2005).

\section{Vrste uloga međunarodnih podružnica}

Uočavanje strateške važnosti međunarodnih podružnica je rezultiralo brojnim definicijama uloga međunarodnih podružnica. Brojni istraživači su promatrali različite varijable temeljem kojih su identificirali i potom definirali uloge međunarodnih podružnica. Kao najčešće varijable se spominju stupanj integriranosti s matičnim poduzećem, stupanj integriranosti s lokalnim tržištem te sposobnosti međunarodnih podružnica. Neki autori su koristili kombinacije ovih varijabli s nekim drugim varijablama, dok su neki koristili varijable kao što je opseg odgovornosti koje međunarodne podružnice imaju ili u kojoj mjeri kreiraju dodanu vrijednost za međunarodno poduzeće. U nastavku se nalazi tablica 1. koja kronološki prikazuje autore koji su se bavili ovom temom i najvažnije doprinose njihovih istraživanja. 


\section{Tablica 1 .}

\section{VRSTE ULOGA MEĐUNARODNIH PODRUŽNICA}

\begin{tabular}{|c|c|c|c|c|c|c|c|}
\hline \multirow[b]{3}{*}{ Autori } & \multirow[b]{3}{*}{$\begin{array}{l}\text { Objekti } \\
\text { istraživanja }\end{array}$} & \multirow[b]{3}{*}{ Uzorak } & \multirow[b]{3}{*}{ Varijable 1 i 2} & \multicolumn{4}{|c|}{ Vrste uloga međunarodnih podružnica } \\
\hline & & & & \multicolumn{4}{|c|}{ Utjecaj varijabli } \\
\hline & & & & $\begin{array}{l}\text { Nizak utjecaj } \\
\text { varijable } 1 / \\
\text { Nizak utjecaj } \\
\text { varijable } 2\end{array}$ & $\begin{array}{l}\text { Visok utjecaj } \\
\text { varijable 1/ } \\
\text { Nizak utjecaj } \\
\text { varijable 2 }\end{array}$ & $\begin{array}{l}\text { Nizak utjecaj } \\
\text { varijable } 1 / \\
\text { Visok utjecaj } \\
\text { varijable } 2\end{array}$ & \begin{tabular}{|c} 
Visok utjecaj \\
varijable 1/ \\
Visok utjecaj \\
varijable 2
\end{tabular} \\
\hline $\begin{array}{c}\text { White i } \\
\text { Poynter } \\
(1984)\end{array}$ & $\begin{array}{l}\text { međunarodna } \\
\text { podružnica }\end{array}$ & $\begin{array}{c}\text { međunarodne } \\
\text { podružnice na } \\
\text { području Kanade }\end{array}$ & tržište i proizvod & $\begin{array}{l}\text { minijaturna } \\
\text { replica }\end{array}$ & $\begin{array}{l}\text { minijaturna } \\
\text { replika }\end{array}$ & $\begin{array}{l}\text { ekspert za } \\
\text { proizvod }\end{array}$ & $\begin{array}{l}\text { strateški } \\
\text { neovisan } \\
\text { entitet }\end{array}$ \\
\hline $\begin{array}{c}\text { White i } \\
\text { Poynter } \\
(1984)\end{array}$ & $\begin{array}{l}\text { međunarodna } \\
\text { podružnica }\end{array}$ & $\begin{array}{c}\text { međunarodne } \\
\text { podružnice na } \\
\text { području Kanade }\end{array}$ & $\begin{array}{l}\text { tržište i kreiranje } \\
\text { dodane vrijednosti }\end{array}$ & $\begin{array}{c}\text { marketinški } \\
\text { satelit }\end{array}$ & $\begin{array}{l}\text { minijaturna } \\
\text { replika }\end{array}$ & $\begin{array}{l}\text { racionalni } \\
\text { proizvođač }\end{array}$ & $\begin{array}{l}\text { strateški } \\
\text { neovisan } \\
\text { entitet }\end{array}$ \\
\hline $\begin{array}{c}\text { Barlett i } \\
\text { Gloshal } \\
(1986)\end{array}$ & $\begin{array}{l}\text { međunarodna } \\
\text { podružnica }\end{array}$ & $\begin{array}{c}518 \\
\text { međunarodnih } \\
\text { podružnica }\end{array}$ & $\begin{array}{l}\text { strateška važnost } \\
\text { tržǐšta i sposobnost } \\
\text { međunarodnih } \\
\text { podružnica }\end{array}$ & crna rupa & $\begin{array}{l}\text { lokalni imple- } \\
\text { mentator }\end{array}$ & kontributor & strateški vođa \\
\hline $\begin{array}{c}\text { Jarillo i } \\
\text { Marinez } \\
(1990)\end{array}$ & $\begin{array}{l}\text { međunarodna } \\
\text { podružnica }\end{array}$ & $\begin{array}{c}50 \text { međunarodnih } \\
\text { podružnica } \\
\text { na području } \\
\text { Španjolske } \\
\end{array}$ & $\begin{array}{c}\text { integracija s } \\
\text { matičnim poduzećem } \\
\text { i integracija s lokal- } \\
\text { nim tržištem } \\
\end{array}$ & $\begin{array}{l}\text { nije defini- } \\
\text { rano }\end{array}$ & Preuzimatelj & neovisna & aktivna \\
\hline $\begin{array}{c}\text { Gupta i } \\
\text { Govindarajan } \\
\text { (1991) }\end{array}$ & $\begin{array}{l}\text { međunarodna } \\
\text { podružnica }\end{array}$ & $\begin{array}{l}70 \text { međunarodnih } \\
\text { podružnica na } \\
\text { području Velike } \\
\text { Britanije }\end{array}$ & $\begin{array}{c}\text { prijenos znanja u i } \\
\text { izvan međunarodnih } \\
\text { podružnica } \\
\text { unutar granica } \\
\text { međunarodnog } \\
\text { poduzeća } \\
\end{array}$ & $\begin{array}{l}\text { lokalni } \\
\text { inovator }\end{array}$ & implementator & $\begin{array}{l}\text { globalni } \\
\text { inovator }\end{array}$ & $\begin{array}{l}\text { integrirani } \\
\text { igrač }\end{array}$ \\
\hline $\begin{array}{l}\text { Roth i } \\
\text { Morrison } \\
(1992)\end{array}$ & $\begin{array}{l}\text { međunarodna } \\
\text { podružnica }\end{array}$ & $\begin{array}{l}115 \text { poslovnih } \\
\text { odjela }\end{array}$ & $\begin{array}{l}\text { sposobnost i } \\
\text { međuovisnost }\end{array}$ & $\begin{array}{l}\text { ekspert za } \\
\text { lokalne } \\
\text { proizvode }\end{array}$ & $\begin{array}{l}\text { međunarodni } \\
\text { ekspert za } \\
\text { inovacije u } \\
\text { proizvodima } \\
\end{array}$ & $\begin{array}{l}\text { međunarodni } \\
\text { strateg }\end{array}$ & $\begin{array}{l}\text { kvazi- } \\
\text { globalni } \\
\text { strateg }\end{array}$ \\
\hline $\begin{array}{l}\text { Birkinshaw } \\
\text { i Morrison } \\
(1995)\end{array}$ & $\begin{array}{l}\text { međunarodna } \\
\text { podružnica }\end{array}$ & $\begin{array}{c}50 \text { međunarodnih } \\
\text { podružnica } \\
\text { na području } \\
\text { Španjolske } \\
\end{array}$ & $\begin{array}{c}\text { autonomija i } \\
\text { integracija aktivnosti }\end{array}$ & $\begin{array}{l}\text { nije defini- } \\
\text { rano }\end{array}$ & $\begin{array}{l}\text { lokalni imple- } \\
\text { mentator }\end{array}$ & kontributor & strateški vođa \\
\hline $\begin{array}{l}\text { Taggart } \\
(1997)\end{array}$ & $\begin{array}{l}\text { međunarodna } \\
\text { podružnica }\end{array}$ & $\begin{array}{l}171 \text { međunarodna } \\
\text { podružnica u UK }\end{array}$ & $\begin{array}{l}\text { integracija s } \\
\text { matičnim poduzećem } \\
\text { i područja aktivnosti }\end{array}$ & pasivna & Receptivna & neovisna & aktivna \\
\hline $\begin{array}{c}\text { Taggart } \\
(1998) \\
\end{array}$ & $\begin{array}{c}\text { međunarodna } \\
\text { podružnica }\end{array}$ & $\begin{array}{l}171 \text { međunarodna } \\
\text { podružnica u UK }\end{array}$ & $\begin{array}{l}\text { koordinacija i } \\
\text { konfiguracija }\end{array}$ & samoodrživa & Detaširana & saveznik & $\begin{array}{c}\text { strateški } \\
\text { asistent }\end{array}$ \\
\hline Solber (2000) & $\begin{array}{l}\text { međunarodno } \\
\text { poduzeće }\end{array}$ & Teorijski koncepti & $\begin{array}{l}\text { znanje o tržištu i } \\
\text { autonomija }\end{array}$ & civilni rat & lokalni barun & federacija & konfederacija \\
\hline
\end{tabular}

Izvor: Paterson, S. L. i Brock, D. M. (2002.), The development of subsidiary-management research: review and theoretical analysis, International Business Review, 11(2): 145. 
Najranija istraživanja na ovu temu datiraju iz 1984. kada su White i Poynter na temelju diskusije s menadžerima međunarodnih podružnica identificirali uloge koje međunarodne podružnice mogu obnašati. Identificirali su jedne vrste uloga temeljem varijabli proizvod i tržište i druge vrste uloga temeljem varijabli tržište i kreiranje dodane vrijednosti. Obzirom na varijable proizvod i tržište gdje proizvod podrazumijeva jačinu utjecaja međunarodnih podružnica s obzirom na proširenje postojećih proizvodnih linija, a tržište veličinu ili broj tržišta na kojima posluju, razlikuju se četiri vrste uloga. Prva je uloga minijaturnih replika u kojoj međunarodne podružnice kopiraju matično poduzeće i pasivno provode njihovu strategiju. U slučaju većeg broja tržišta na kojem djeluju i s niskom razinom utjecaja na proizvodne linije (moguće i bez utjecaja), međunarodne podružnice također preuzimaju ulogu minijaturnih replika jer i dalje „,samo“ provode strategiju matičnog poduzeća. Kod veće razine utjecaja na proizvodne linije i manje veličine tržišta, međunarodne podružnice preuzimaju uloge stručnjaka za proizvod. U slučaju kad su obje varijable visoke, veličina tržišta i razina utjecaja na proizvodne linije, međunarodne podružnice preuzimaju uloge strateški neovisnog entiteta (White i Poynter, 1984). S druge strane, obzirom na varijable tržište i kreiranje dodane vrijednosti, gdje se varijabla kreiranja dodane vrijednosti odnosi na mjeru u kojoj je kreirana dodana vrijednost (kroz razvoj, proizvodnju ili marketinške aktivnosti). Mjera u kojoj se kreira dodana vrijednost se smatra velikom ako su međunarodne podružnice sposobne razviti novi proizvod ili novi poslovni proces. Ulogu marketinških satelita međunarodne podružnice preuzimaju u slučaju manjeg broja tržišta te niske (ili gotovo nikakve) razine kreiranja dodane vrijednosti. Zatim se ponovo pojavljuje uloga minijaturnih replika koju preuzimaju u slučaju većeg broja tržišta, ali niske razine kreiranja dodane vrijednosti. Kod malog broja tržišta i visoke razine kreiranja vrijednosti javlja se uloga racionalnih proizvođača, a u slučaju visokih vrijednosti obiju varijabli, međunarodne podružnice preuzimaju ulogu strateški neovisnih entiteta kao što je to bio slučaj kod većeg utjecaja na proizvodne linije (White i Poynter, 1984).

Slično tome, Bartlett i Ghoshal (1986) su u svom istraživanju uzeli u obzir dvije varijable, sposobnost međunarodnih podružnica i stratešku važnost lokalnog tržišta. Kao i u prethodnom primjeru, s obzirom na vrijednosti koje varijable poprimaju, međunarodne podružnice obnašaju određene uloge. Ovdje se javljaju četiri uloge, uloga strateškog vođe, uloga kontributora, uloga implementatora te uloga crne rupe (eng. the black hole). Međunarodne podružnice koje karakterizira uloga strateškog vođe posluju na tržištima od strateške važnosti za međunarodno poduzeće te djeluju kao „partneri“ matičnom poduzeću u razvoju i implementaciji strategije. Ulogu kontributora podrazumijeva posjedovanje specifičnih sposobnosti koje se koriste za razvijanje poslovanja. Kontributori posluju na malim i strateški manje važnim tržištima. Implementatori su, kako i sama riječ kaže, oni koji pasivno implementiraju odnosno provode strategiju matičnog poduzeća. Takve međunarodne po- 
družnice posluju na malim i strateškim manje važnim tržištima te nemaju razvijene specifične sposobnosti. U slučaju uloge crne rupe, međunarodne podružnice posluju na velikim tržištima od visoke strateške važnosti za međunarodno poduzeće, ali s loše razvijenim sposobnostima. Zauzimanje pozicije na takvom tržištu je prilično teško, skupo i zahtjeva puno vremena s obzirom na mnoštvo drugih jakih konkurenata koji su već pozicionirani na tržištu (Ghoshal i Bartlett, 1986).

Sljedeće važno istraživanje na ovu temu je provedeno u Španjolskoj na uzorku 50 međunarodnih podružnica uzimajući u obzir dvije varijable, integriranost s matičnim poduzećem te integriranost s lokalnim tržištem. Identificirane su tri uloge koje međunarodne podružnice mogu preuzeti s obzirom na razinu spomenutih varijabli, uloga preuzimatelja, uloga neovisnih međunarodnih podružnica te aktivna uloga. U slučaju niskih vrijednosti varijabli uloga nije definirana. Uloga preuzimatelja je definirano u situaciji visoke integracije s matičnim poduzećem, ali niske integracije s lokalnim tržištem. Uloga neovisnih međunarodnih podružnica se javlja kod niske integracije s matičnim poduzećem i visoke integracija s lokalnim tržištem, dok se aktivna uloga identificira u slučaju visoke integracije i s matičnim poduzećem i s lokalnim tržištem (Jarillo i Martíanez, 1990).

Gupta i Govindarajan (1991) razvijaju vrsta uloge s obzirom na prijenos znanja u i izvan međunarodnih podružnica unutar granica međunarodnog poduzeća. Varijable, koje su se koristile prilikom identifikacije uloga, su mjera u kojoj je međunarodna podružnica korisnik znanja preuzetog od ostataka međunarodnog poduzeća (drugih međunarodnih podružnica) i mjera u kojoj je međunarodna podružnica pružatelj takve vrste znanja ostatku međunarodnog poduzeća (odnosno drugim međunarodnim podružnicama). Vrste uloga koje se ovdje javljaju su lokalni inovator, prilikom niske razine primanja i dijeljenje znanja, implementator kod visoke razine primanja, ali niske razine dijeljenja znanja, globalni inovator kod niže razine primanja, ali visoke razine dijeljenja znanja te integrirani igrač prilikom visoke razine i dijeljenja i primanja znanja (Gupta i Govindarajan, 1991).

Roth i Morrison (1992) su identificirali vrste uloga međunarodnih poduzeća stavljajući u matricu sposobnosti međunarodnih podružnica i njihovu međuovisnost unutar međunarodnog poduzeća. Njihovo istraživanje je iznjedrilo četiri uloge: ulogu eksperta za lokalne proizvode, ulogu međunarodnog eksperta za inovacije u proizvodima, uloga međunarodnih stratega te ulogu kvazi-globalnih stratega. Uloga lokalnog eksperta podrazumijeva nisku razinu međuovisnost unutar međunarodnog poduzeća kao i nedovoljno razvijene sposobnosti. Uloga međunarodnog eksperta za inovacije u proizvodima se javlja kod razvijenih sposobnosti i niskog stupnja međuovisnosti, uloga međunarodnog stratega kod nerazvijenih sposobnosti, ali visoke međuovisnosti unutar međunarodnog poduzeća te uloga kvazi-globalnih stratega kod razvijenih sposobnosti i visoke međuovisnosti (Roth i Morrison, 1992). 
Birkinshaw i Morrison (1995) su temeljem stupnja autonomije i integracije aktivnosti definirali tri uloge: lokalni implementatori, kontributori te strateški vođe. Uloga lokalnih implementatora podrazumijeva visoku integriranost s matičnim poduzećem gdje je najvažnije prilagoditi proizvod međunarodnog poduzeća potrebama lokalnog tržišta. Kod nje je integracija aktivnosti visoka, a stupanj autonomije nizak. Kontributori obuhvaćaju visok stupanj autonomije i nisku integraciju aktivnosti. Ta uloga je usporediva s ulogom preuzimatelja kod Jarilla i Martianeza (1990). Treća uloga se odnosi na ulogu strateških vođa gdje međunarodne podružnice imaju visok stupanj autonomije i visoku integraciju s matičnim poduzećem. U potonjem slučaju međunarodne podružnice zajedno s matičnim poduzećem razvijaju i implementiraju strategiju međunarodnog poduzeća (Birkinshaw i Morrison, 1995).

Taggart (1997) je detektirao nove vrste uloga s obzirom na integraciju s matičnim poduzećem i odgovornosti međunarodnih podružnica, a riječ je o pasivnoj, receptivnoj, neovisnoj i aktivnoj ulozi. Međunarodne podružnice s niskim stupnjem integriranosti s matičnim poduzećem i suženog područja odgovornosti preuzimaju pasivnu ulogu, kod visoke integriranosti s matičnim poduzećem i suženog područja odgovornosti preuzimaju receptivnu ulogu, kod niske integriranosti s matičnim poduzećem i širokog područja odgovornosti preuzimaju neovisnu ulogu, a kod visoke integriranosti s matičnim poduzećem i širokog područja odgovornosti preuzimaju aktivnu ulogu. Godinu dana kasnije Taggart (1998) je proveo slično istraživanje na gotovo identičnom uzorku (međunarodne podružnica na području Velike Britanije) i došao do novih vrsta uloga koristeći se pritom varijablama koordinacija i konfiguracija. Nove uloge su uloga samoodrživih međunarodnih podružnica, uloga detaširanih međunarodnih podružnica, uloga saveznika te uloga strateških asistenata. Uloga samoodrživih međunarodnih podružnica javlja se prilikom niske koordinacije i niske konfiguracije, uloga detaširanih međunarodnih podružnica kod visoke koordinacije i niske konfiguracije, uloga saveznika kod niske koordinacije i visoke konfiguracije te uloga strateških asistenata kod visoke koordinacije i visoke konfiguracije (Taggart, 1998).

Nešto novije istraživanje je proveo Solber (2000) koristeći se varijablama znanje o tržištu i autonomija. Ovisno o njihovoj razini definirao je četiri vrste uloga. Kod niske autonomije i malog (nikakvog) znanja o tržištu, ,civilni rat“" (eng. civil war) je uloga koja je dodijeljena međunarodnim podružnicama. Civilni rat se definira kao konflikt između vodstva i drugih subjekata na istom tržištu. U ovom slučaju radi se o konfliktu između matičnog poduzeća i ostalih sudionika tržišta (konkurencija, kupci, dobavljači). Prilikom niskog znanja o tržištu i visoke autonomije definirana je uloga „lokalnih baruna“ (eng. local baron), zatim kod visokog znanja o tržištu, ali s nižim stupnjem autonomije, definirana je uloga u kojoj su matično poduzeće i međunarodne podružnice u federaciji (eng. federation), dok je kod visokog znanja i visokog stupnja autonomije definirana uloga u kojoj su matično poduzeće i međuna- 
rodne podružnice u konfederaciji (eng. confederation) gdje konfederacija i federacija podrazumijevaju zajednicu više jedinica, s razlikom što se kod konfederacije smatra kako jedinice imaju više autonomije od jedinica koje se nalaze u federaciji.

Literature potvrđuje kako međunarodne podružnice imaju neku vrstu uloge koje obnašaju unutar međunarodnog poduzeća i na ovaj ili onaj način doprinose matičnom poduzeću. Od svih spomenutih varijabli, integriranost i autonomija su značajno prisutne u gotovo svim vrstama uloga. Zaključno je važno istaknuti kako interakcija između matičnog poduzeća i međunarodnih podružnica i utjecaj lokalnog tržišta na poslovanje međunarodnih podružnica su krucijalni u definiranju njihovih uloga i odgovornosti.

\section{Specifičnosti razvoja međunarodnih podružnica}

Upravljanje međunarodnim podružnicama je termin koji se odnosi na pojam razvoja međunarodnih podružnica koji može biti promatran prema matičnom poduzeću, ali i u zemlji u kojoj se nalazi međunarodna podružnica. Tržišta na kojem djeluju međunarodne podružnice će biti od strateške važnosti kod njenog razvoja prema matičnom poduzeću, i isto tako, njihov razvoj na lokalnom tržištu će ovisiti o povezanosti i odnosu s matičnim poduzećem. Pojam lokalno tržište u ovom radu se odnosi na tržišta na kojem djeluju međunarodne podružnice. U literaturi se pojavljuju i nazivi tržište domaćina (eng. host market) ili domaće tržište.

Prema Birkinshaw (2016) postoje tri različita faktora utjecaja na razvoj međunarodnih podružnica: faktor međunarodnog poduzeća, faktor međunarodne podružnice i faktor lokalnog tržišta. Faktor međunarodnog poduzeća između ostalih $^{1}$ uključuje promjene u područjima odgovornosti međunarodnih podružnica, promjene njihovih sposobnosti, razvoju tehnologije te centraliziranosti upravljanja (Bartlett i Ghoshal, 1986). Faktor međunarodne podružnice uključuje poslovne rezultate, kredibilitet i poduzetnički duh međunarodnih podružnica (Birkinshaw, Hood i Jonsson, 1998). Posljednji faktor, faktor lokalnog tržišta, uključuje razvijenost gospodarstva i politike na tržištu na kojem međunarodne podružnice posluju (Birkinshaw, Hood i Young, 2005). Temeljem navedena tri faktora u nastavku slijedi razvoj međunarodnih podružnica kako prema matičnom poduzeću tako i na domaćem tržištu.

${ }^{1}$ Ovaj faktor uključuje i promjene na globalnom tržištu, dostupnost resursa, globalna restrukturiranja, konkurenciju u vidu ostalih međunarodnih podružnica, ali one ovdje nisu toliko zastupljene jer su izvan kontrole matičnih poduzeća i na njih je teško utjecati. Prema Birkinshaw, J. i Hood., N. (1998.), Multinational Subsidiary Evolution: Capability and Charter Change in ForeignOwned Subsidiary Companies, Academy of Management Review, 23(4): 773-795. 
Razvoj međunarodnih podružnica prema matičnom poduzeću ovisi o faktorima međunarodnog poduzeća kao i faktorima međunarodne podružnice. Sposobnosti, kao faktor međunarodnih podružnica, predstavljaju prilagodbu, povezivanje i rekonfiguraciju vanjskih i unutarnjih organizacijskih resursa u skladu s promjenjivom okolinom (Teece, Pisano i Shuen, 1997). Sposobnosti su u principu vještine poduzeća da na pravi način modificira i iskoristi postojeće resurse i/ili proizvede nove. Sposobnosti se ne mogu kupiti nego se razvijaju unutar poduzeća i specifične su za svako pojedino poduzeće (Teece, 2010). Postoje dvije teorije koje se bave sposobnostima poduzeća, resursna teorija i teorija dinamičkih sposobnosti. I dok se prema resursnoj teoriji trenutne sposobnosti poduzeća iskorištavaju u skladu s prilikama na tržištu (Barney i Clark, 2007), teorija dinamičkih sposobnosti podrazumijeva razvijanje novih sposobnosti unutar poduzeća kako bi pomoću njih identificirali nove prilike na tržištu i onda ih brzo iskoristili (Montealegre, 2002). Svako poduzeće razvija splet sposobnosti koji su samo njima svojstveni i rezultat su integriranosti s tržištem, prethodnim razvojem, obvezama i zahtjevima okoline (Erdil, Kitapci i Timurlenk, 2010).

Područja odgovornosti, kao faktor međunarodnog poduzeća, su imanentna međunarodnim podružnicama i određena su svojevrsnim „ugovorom“ (eng. charter) između matičnog poduzeća i međunarodnih podružnica. Područja odgovornosti se odnose na tržišta koja će međunarodna podružnica opsluživati, koje će proizvode proizvoditi, koju će tehnologiju koristiti, koja će funkcijska područja pokrivati, ili bilo koju kombinaciju navedenog. Ugovor predstavlja zajedničko razumijevanje područja odgovornosti djelovanja međunarodnih podružnica između matičnog poduzeća i međunarodnih podružnica (Rugman, 2002).

Sposobnosti međunarodnih podružnica se u nekom dijelu razlikuju od sposobnosti matičnog poduzeća i sposobnosti ostalih međunarodnih podružnica. Drugim riječima, određeni geografski i povijesni faktori su odgovorni za definiranje smjera razvijanja koji naposljetku rezultira sposobnostima specifičnim za međunarodnu podružnicu. Postoje također i sposobnosti koje dvije ili više međunarodnih podružnica međusobno dijele, kao na primjer shematski prikazi novog proizvoda ili procesa (eng. blueprint) ili one koje su definirane u područjima odgovornosti odnosno ugovorima koje imaju s matičnim poduzećem. Sposobnosti su, najjednostavnije rečeno, ,ljepljive“ i ne mogu lako biti transferirane iz jedne međunarodne podružnice u drugu, čak i u situacijama kad se radi o transferu kojeg one same podupiru (Birkinshaw i Hood, 1998).

Veza između sposobnosti i područja odgovornosti nije baš jednostavna. U slučajevima gdje se područja odgovornosti međunarodnih podružnica ne mijenjaju u dužem vremenskom periodu, menadžeri međunarodnih podružnica upravljaju razvojem resursa i akumulacijom sposobnosti težeći promjeni područja odgovornosti kako bi njihove sposobnosti postale odraz područja odgovornosti propisanih 
ugovorom od strane matičnog poduzeća. Ukoliko dođe do velikih promjena unutar poslovanja međunarodnih podružnica (na primjer zbog spajanja i preuzimanja) ili u promjenama na tržištu na kojem međunarodna podružnica djeluje, može se desiti raskorak između sposobnosti međunarodnih podružnica i dogovorenih područja odgovornosti (Rugman, 2002).

Razvoj međunarodnih podružnica prema matičnom poduzeću rezultat je akumulacije i eksploatacije sposobnosti tijekom vremena (Teece, Pisano i Shuen, 1997). Sposobnosti međunarodnih podružnica se razvijaju tijekom vremena i pod jakim su utjecajem različitih faktora kao što su matično poduzeće, druge međunarodne podružnica, lokalni i ostali faktori (Birkinshaw i Hood, 1998). S druge strane dogovorena područja odgovornosti također utječu na razvoj međunarodnih podružnica pa se može reći kako je razvoj međunarodnih podružnica prema matičnom poduzeću rezultat promjena sposobnosti i promjena definiranih područja odgovornosti (Birkinshaw i Hood, 1998).

Faktori međunarodnog poduzeća, međunarodnih podružnica i lokalnog tržišta utječu na promjene sposobnosti i promjene područja odgovornosti što rezultira razvojem međunarodnih podružnica prema matičnom poduzeću. U nastavku u tablici 2. prikazani su načini na koji se mijenjaju sposobnosti i područja odgovornosti, a potom i slika 2. koja pokazuje utjecaj promjena sposobnosti i područja odgovornosti na razvoj međunarodnih podružnica prema matičnom poduzeću. 
Tablica 2.

\section{UTJECAJ FAKTORA MATIČNOG PODUZEĆA, MEĐUNARODNE PODRUŽNICE I LOKALNOG TRŽIŠTA NA PROMJENE U SPOSOBNOSTIMA I PODRUČJIMA ODGOVORNOSTI MEĐUNARODNIH PODRUŽNICA}

\begin{tabular}{|c|c|c|}
\hline Kontekstualni faktori & Akcija & Ishod akcije \\
\hline \multirow{5}{*}{$\begin{array}{l}\text { Faktori matičnog } \\
\text { poduzeća, } \\
\text { međunarodne } \\
\text { podružnice i lokalnog } \\
\text { tržišta }\end{array}$} & $\begin{array}{l}\text { matično poduzeće donosi odluku o } \\
\text { ulaganju i evaluira moguće lokacije; } \\
\text { međunarodna podružnica lobira }\end{array}$ & $\begin{array}{l}\text { međunarodna podružnica } \\
\text { dobiva nova područja } \\
\text { odgovornosti što doprinosi } \\
\text { proporcionalnom razvoju } \\
\text { sposobnosti }\end{array}$ \\
\hline & $\begin{array}{l}\text { međunarodna podružnica identificira } \\
\text { priliku, razvija sposobnosti; i daje } \\
\text { prijedlog iskorištavanja uočene prilike }\end{array}$ & $\begin{array}{l}\text { proširenje područja } \\
\text { odgovornosti }\end{array}$ \\
\hline & $\begin{array}{l}\text { međunarodna podružnica vođena } \\
\text { stupnjem konkurentnosti interne mreže } \\
\text { ulaže u razvoj sposobnosti }\end{array}$ & $\begin{array}{l}\text { promjene postojećih } \\
\text { odgovornosti }\end{array}$ \\
\hline & $\begin{array}{l}\text { matično poduzeće odlučuje povući } \\
\text { ulaganje; međunarodna podružnica } \\
\text { lobira }\end{array}$ & $\begin{array}{l}\text { smanjenje ili gubitak } \\
\text { područja odgovornosti I } \\
\text { atrofiranje sposobnosti }\end{array}$ \\
\hline & $\begin{array}{l}\text { međunarodna podružnica je } \\
\text { pasivna, sposobnosti su joj atrofirale; } \\
\text { matično poduzeće osuđuje manjak } \\
\text { konkurentnosti }\end{array}$ & $\begin{array}{l}\text { gubitak ili smanjenje } \\
\text { odgovornosti }\end{array}$ \\
\hline
\end{tabular}

Izvor: Paterson, S. L. i Brock, D. M. (2002.), The development of subsidiary-management research: review and theoretical analysis, International Business Review, 11(2): 146.

U slučajevima kad matično poduzeće odluči ulagati u nove proizvode, poboljšanje postojećih proizvoda, istraživanje i razvoj, uvođenje novih internih procesa i slično, svaka od međunarodnih podružnica želi biti ona koja će provesti to ulaganje jer to posljedično utječe na proširenje područja odgovornosti, razvija sposobnosti i naposljetku ih čini konkurentnijima. Kod povlačenja ulaganja međunarodne podružnice pokušavaju lobirati kako bi se matično poduzeće predomislilo. U slučaju povlačenja, dolazi do gubitka definiranog područja odgovornosti i do atrofiranja njenih sposobnosti što naposljetku rezultira manjkom konkurentnosti (Paterson i Brock, 2002). 
Slika 2.

\section{UTJECAJ PROMJENA SPOSOBNOSTI I PODRUČJA ODGOVORNOSTI NA RAZVOJ MEĐUNARODNIH PODRUŽNICA PREMA MATIČNOM PODUZEĆU}

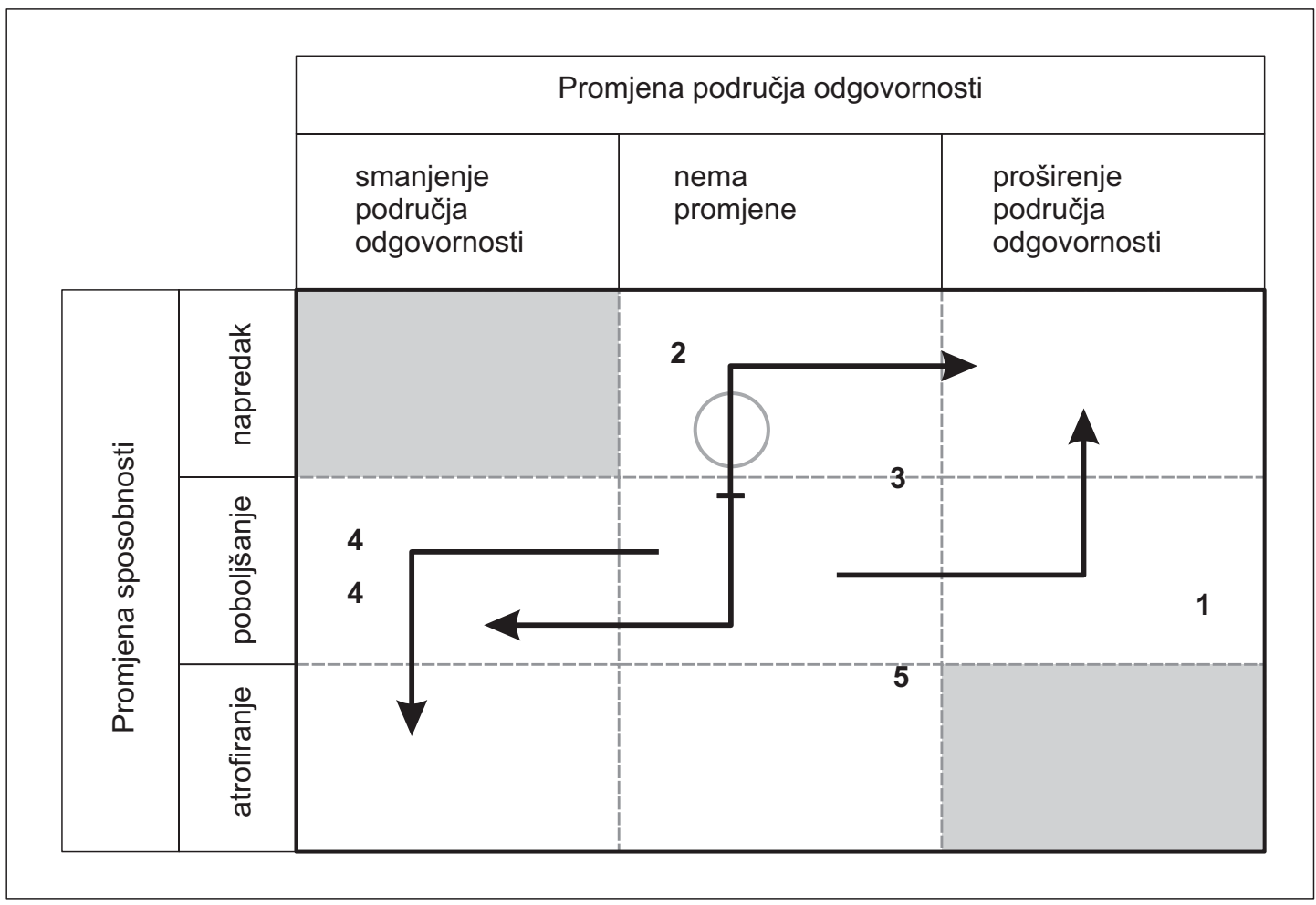

Izvor: Birkinshaw, J. i Hood, N. (1998.), Multinational subsidiary evolution: capability and charter change in foreign-owned subsidiary companies, Academy of Management Review, 23(4): 783.

Slika 2. ukazuje na moguće kombinacije promjena sposobnosti i promjena područja odgovornosti međunarodnog poduzeća. U prvom kvadrantu proširenje područja odgovornosti vodi prema poboljšanju sposobnosti. Ako je proširenje područja odgovornosti djelo matičnog poduzeća, i sposobnosti još uvijek ne postoje (jer su u procesu razvijanja), ovaj proces se generički naziva ulaganje uz poticaj matičnog poduzeća (eng. parent driven investment). Iako menadžeri međunarodnih podružnica u ovom slučaju mogu imati određen utjecaj na sam proces (putem izvrsnih poslovnih rezultata), oni se uglavnom bore s menadžerima drugih međunarodnih podružnica za proširenjem odgovornosti, tako da razvijanje sposobnosti počinje tek kada dobiju proširenje područja odgovornosti (Birkinshaw i Hood, 1998). 
U drugom kvadrantu razvijanje sposobnosti posljedično vodi prema proširivanju područja odgovornosti. U srži, predstavlja strateški pomak menadžera međunarodnih podružnica koji vide priliku u prisvajanju novih odgovornosti ili barem proširenju postojećih odgovornosti ukoliko demonstriraju svoje sposobnosti za nove ili proširene odgovornosti. U ovom slučaju promjena u području odgovornosti nije zagarantirana. Navedeni proces se naziva proširenje odgovornosti na inicijativu međunarodnih podružnica (eng. subsidiary-driven charter extension) (Rugman, 2002).

Treći kvadrant predstavlja iniciranje proširenja područja odgovornosti od strane međunarodne podružnice. Navedeno se odnosi na situacije u kojima međunarodne podružnice ulažu i razvijaju trenutne sposobnosti kako bi rezultiralo stjecanjem odgovornosti. U četvrtom i petom kvadrantu su prikazani modaliteti suprotni prvom i drugom. Četvrti modalitet podrazumijeva gubitak ili smanjenje područja odgovornosti, bilo vezano uz određeni proizvod, tehnologiju ili tržište, pa posljedično njene sposobnosti atrofiraju. Peti kvadrant predstavlja atrofiju uzrokovanu zanemarivanjem međunarodne podružnice. Sposobnosti međunarodne podružnice vremenom postepeno atrofiraju, zbog čega poslovni rezultati postaju sve lošiji i na kraju matično poduzeće oduzima odgovornosti međunarodnoj podružnici (Birkinshaw i Hood, 1998).

U kontekstu razvoja međunarodne podružnice na lokalnom tržištu, važno je istaknuti kako navedeno obuhvaća interakcije s lokalnim kupcima, dobavljačima i ostalim interesno-utjecajnim skupinama s ciljem ostvarivanja što boljih poslovnih rezultata što posljedično dovodi do rasta i razvoja međunarodnih podružnica. Teorija organizacije promatra organizacijsko djelovanje kao ograničeno odnosno određeno tržištem na kojem se pojavljuje (Hannan i Freeman, 1977). Teoretičari koji analiziraju međunarodne podružnice su prilagodili tu perspektivu predlažući da svaka međunarodna podružnica posluje na svom lokalnom tržištu koje ograničava ili određuje aktivnosti i sukladno tome razvoj međunarodne podružnice ovisi o okruženju u kojem se nalaze (Ghoshal i Bartlett, 1990). Iako je proučavan statički odnos između međunarodnih podružnica i njihovih lokalnih tržišta (Andersson i Forsgren, 1996), manje pažnje je posvećeno proučavanju možda i puno važnijeg, dinamičnijeg pitanja - odnosa između lokalnog / regionalnog razvoja tržišta i razvoja same međunarodne podružnice (Young, Hood i Peters, 1994).

Ključan problem identificiran u radovima koji se bave odnosom lokalnog tržišta i međunarodne podružnice je činjenica da se određena znanja učinkovitije prenose između međunarodnih poduzeća (u potpunom vlasništvu ili u nepotpunom vlasništvu), nego između matičnog poduzeća i međunarodnih podružnica, zbog geografske blizine i kulturne sličnosti (Kogut i Zander, 1992).

Postoje čvrsti dokazi da je razvoj međunarodne podružnice u zemlji pod velikim utjecajem lokalnog tržišta kroz dinamiku i aktivnosti lokalnog poslovanja. 
Velik broj znanstvenika obrađuje početne faze razvoja podružnica, dok se daljnji koraci i razvoj ipak prate s puno manje pozornosti. U novije vrijeme međunarodne podružnice same traže prilike na lokalnom tržištu kako bi razvile svoje poslovanje i proširile svoje odgovornosti (Birkinshaw, 1995).

Uzimajući u obzir tradicionalne poglede, kao što je primjerice model životnog ciklusa proizvoda, na modele razvoja međunarodnih poduzeća, međunarodne podružnice su imale točno definirane zadatke koje su provodile poslujući u skladu s pravilima matičnog poduzeća. Matično poduzeće bi razvilo novi proizvod ili uslugu (Vernon, 1966), a međunarodna podružnica je imala određenu slobodu odlučivanja prilikom nalaženja najboljeg načina prodaje na lokalnom tržištu. Danas je situacija puno kompleksnija jer postoje međunarodne podružnice odgovorne za prodaju i marketing s globalnim odgovornostima, zatim međunarodne podružnice koje imaju proizvodne pogone i eksterne kupce, međunarodne podružnice koje imaju interne kupce, međunarodne podružnice koje se bave isključivo istraživanjem i razvojem i mnoge druge.

Novi trendovi su utjecali na smanjenje slobode odlučivanja međunarodnih podružnica kada je riječ o lokalnim kupcima i načinima plasiranja proizvoda ili usluga na tržište. Drugim riječima, aspekti strategije koji su tržišno orijentirani, su sada pod većim ograničenjem i do nekog stupnja izbačeni iz potpune kontrole menadžera međunarodnih podružnica (Birkinshaw i Hood, 1998).

Najzanimljivija je činjenica da se u isto vrijeme pojavio i trend osnaživanja, kojim matična poduzeća podupiru poduzetnički duh međunarodnih podružnica (Bartlett i Ghoshal, 1997). S jedne strane menadžeri međunarodnih poduzeća su ograničeni u aktivnostima vezanim uz lokalno tržište, a na drugu stranu ih se potiče na poduzetničko ponašanje i traženje novih prilika za stvaranje vrijednosti za poduzeće. Navedeno dovodi do svojevrsnih poteškoća prilikom definiranja razvoja međunarodnih podružnica u zemlji.

Zaključno je važno naglasiti kako razvoj međunarodnih podružnica podrazumijeva razvoj prema matičnom poduzeću i u zemlji gdje se nalaze jer će upravo najbolji omjer oba razvoja doprinijeti da međunarodne podružnica zauzmu strateške pozicije naspram matičnog poduzeća.

\section{Zaključak}

Zaključno je važno ukazati kako je upravljanje međunarodnim podružnicama rezultat odnosa matičnog poduzeća i međunarodnih podružnica koji gotovo nikada nije jednostavan. Taj odnos može biti opisan kao ,veza između subjekata s različitim pogledima“" gdje interesi jedne strane nisu usklađeni s interesima druge 
strane (Ghoshal i Nohria, 1989). Primjerice, međunarodna podružnica može inzistirati na većem stupnju autonomije, dok matično poduzeće inzistira na većoj kontroli, ili pak međunarodna podružnica može smatrati kako vrijedi uložiti napor u određenu priliku, dok matično poduzeće to može smatrati oportunističkim ponašanjem na način da međunarodna podružnica primarno djeluje u interesu lokalnog tržišta i da su manje usredotočeni na globalnu profitabilnost međunarodnog poduzeća (Ambos, Andersson i Birkinshaw, 2010). Odnos matičnog poduzeća i međunarodne podružnice u praksi nije eksplicitno definiran, nego se razvija u međusobnoj interakciji (Dörrenbächer i Geppert, 2006). Strateški aspekti odnosa mogu biti pod utjecajem matičnog poduzeća, ali i pod utjecajem samih međunarodnih podružnica. Oni mogu biti promišljeno dizajnirani tako da ispune određenu svrhu ili mogu biti razvijeni pod utjecajem određenih okolnosti (Brock i Barry, 2003). Kakav će odnos biti između matičnog poduzeća i međunarodnih podružnica ovisi o pregovaranju između menadžera matičnog poduzeća i menadžera međunarodne podružnice. Razlog zašto neke međunarodne podružnice imaju bolji odnos s matičnim poduzećem od drugih međunarodnih podružnica nije definiran isključivo uspješnosti i položajem na lokalnom tržištu, već i uspješnosti i statusom unutar međunarodnog poduzeća. Neke međunarodne podružnice su za međunarodno poduzeće znatno važnije nego ostale, pri čemu veličina, prihodi, tržišna pozicija i funkcionalna uloga određuju količinu moći koja pripada određenoj podružnici (McGraw, 2004).

Novija istraživanja uvode pojam ,novorođenih globalnih podružnica“ koje od početka stvaraju konkurentsku prednost, upravljaju vlastitim resursima i ostvaruju prihode od prodaje u više zemalja. Strateški aspekti upravljanja međunarodnim podružnicama definirani su temeljem varijabli znanje o tržištu i međunarodna poduzetnička orijentacija. Vrhovni menadžeri novorođenih globalnih podružnica posjeduju znanja o tržištu koja su prikupili mnogo ranije od nastanka međunarodne podružnice, pa ih onda primjenjuju u skladu s poslovanjem matičnog poduzeća. Zbog upravo spomenutog znanja o tržištu i izražene međunarodne poduzetničke orijentacije, odnos matičnog poduzeća i međunarodnih podružnica karakterizira autonomija međunarodnih podružnica, orijentacija na lokalne resurse i međunarodne odgovornosti međunarodnih podružnica (Weerawardena, Mort, Liesch i Knight, 2007).

Veći dio istraživanja pretpostavljaju da je matično poduzeće ono koje će ipak imati veći utjecaj na definiranje strateških aspekata odnosa između njih i međunarodnih podružnica. No, u literaturi se pojavio i drugačiji pristup prema kojem međunarodna podružnica sama bira kakav će odnos imate spram matičnog poduzeća. Taj pristup se naziva izbor međunarodne podružnice (eng. subsidiary choice) i pretpostavlja kako međunarodna podružnica ima dovoljno slobode, odnosno dovoljno visok stupanj autonomije, kako bi sama mogla definirati odnos spram međunarodnog poduzeća (Birkinshaw, 1997). Rast i razvoj podružnice je ograni- 
čen aktivnostima drugih sudionika internog tržišta koje koriste njihovu relativnu snagu kako bi ojačale vlastite međunarodne podružnice. Kako međunarodna podružnica povećava udio karakterističnih resursa, tako reducira svoju ovisnost o drugim međunarodnim podružnicama i preuzima puno veću kontrolu nad vlastitom sudbinom (Prahalad i Doz, 1981).

Ovaj pregled literature o strateškim aspektima upravljanja međunarodnih podružnica pokazuje kako je to višeznačan i kompleksan koncept na kojeg se može gledati iz različitih perspektiva. Raznolikost faktora koji utječu na njihov odnos je rezultat toga što je jako teško jednoznačno definirati aspekte njihovog odnosa i upravo te poteškoće u definiranju često dovode do raskoraka u percepciji između menadžera međunarodnih podružnica i menadžera matičnog poduzeća.

\section{Literatura:}

Aharoni, Y. (1971.), Definition of a Multinational Corporation, Quarterly Review of Economics and Business, 11(3): 27-37.

Ambos, T. C., Andersson, U. i Birkinshaw, J. (2010.), What are the consequences of initiative-taking in multinational subsidiaries? Journal of International Business Studies, 41(7): 1099-1118.

Anderson, E. i Gatignon, H. (1986.), Modes of foreign entry: A transaction cost analysis and propositions, Journal of International Business Studies, 17(3): $1-26$.

Barney, J. B. i Clark, D. N. (2007.), Resource-based theory: Creating and sustaining competitive advantage, Oxford University Press, Oxford

Bartlett, C. A. i Ghoshal, S. (1986.), Tap Your Subsidiaries for Global Reach, Harvard Business Review, 64(6): 87-94.

Bartlett, C. A. i Goshal, S. (1989.), Managing across borders: The transnational solution, American Foreign Policy Interests, 21(3): 20-22.

Bartlett, C. A. i Ghoshal, S. (1990.), Managing Innovations in the Transnational Corporation, u: Bartlett, Y. L. i Hedlund, G. (eds.), Managing the Global Firm, London, Routledge, 215-255.

Bartlett, C. A. i Ghoshal, S. (1997.), The myth of the generic manager: new personal competencies for new management roles, California Management Review, 40(1): 92-116.

Birkinshaw, J. (1995.), Entrepreneurship in Multinational Corporations: The Initiative Process in Foreign Subsidiaries, Western Business School, Ontario 
Birkinshaw, J. (1997.), Entrepreneurship in multinational corporations: The characteristics of subsidiary initiatives, Strategic Management Journal, 18(3): 207-229.

Birkinshaw, J. i Fry, N. (1998.), Subsidiary initiatives to develop new markets, Sloan Management Review, 39(3): 51-61.

Birkinshaw, J. i Hood, N. (1998.), Multinational Subsidiary Evolution: Capability and Charter Change in Foreign-Owned Subsidiary Companies, Academy of Management Review, 23(4): 773-795.

Birkinshaw, J. i Hood, N. (2016.), Multinational Corporate Evolution and Subsidiary Development, Springer, London

Birkinshaw, J. i Morrison, A. J. (1995.), Configurations of strategy and structure in subsidiaries of multinational corporations, Journal of International Business Studies, 26(4): 729-753.

Birkinshaw, J., Hood, N., Jonsson, S. (1998.), Building firm-specific advantages in multinational corporations: The role of subsidiary initiative, Strategic Management Journal, 19(3): 221-241.

Birkinshaw, J., Hood, N., Young, S. (2005.), Subsidiary entrepreneurship, internal and external competitive forces, and subsidiary performance, International Business Review, 14(2): 227-248.

Braverman, H. (1983.), Rad i monopolistički kapital, Globus, Zagreb

Brock, D. i Barry, D. (2003.), What if Planning Were Really Strategic? Exploring the Strategy-Planning Relationship in Multinationals, International Business Review, 12(5): 543-561.

Casson, M. (1982.), The entrepreneur: An economic theory, Barnes and Noble books, New Jersey

Dörrenbächer, C. i Geppert, M. (2006.), Micro-Politics and Conflicts in Multinational Corporations: Current Debates, Re-Framing, and Contributions of This Special Issue, Journal of International Management, 12(3): 251-265.

Dunning, J. H. (1982.), Explaining the International Direct Investment Position of Countries: Towards a Dynamic or Developmental Approach, u: Black, J. i Dunning, J. H. (eds), International Capital Movements, Palgrave Macmillan, London, 84-121.

Dunning, J. H. (2010.), New challenges for international business research: back to the future, Edward Elgar Publishing, UK

Erdil, O., Kitapci, H. i Timurlenk, B. (2010.), Effects of core employees on organizational capabilities and firm performance, Journal of Global Strategic Management, 7(1): 30-38. 
M. KOVAČ, D. FILIPOVIĆ, N. PODRUG: Partikularnosti strateškog upravljanja međunarodnim podružnicama

EKONOMSKI PREGLED, 70 (3) 529-553 (2019)

Filipović, D. (2012.), Izazovi integracijskih procesa: rast poduzeća putem spajanja, preuzimanja i strateških saveza, Sinergija, Zagreb

Greer, J. i Sing, S. (2000.), A brief history of transnational corporations, Global Policy Forum, New York

Gupta, A. K. i Govindarajan, V. (1991.), Knowledge flows and the structure of control within multinational corporations, Academy of Management Review, 16(4): 768-792.

Gupta, A. K. i Govindarajan, V. (2000.), Knowledge Flows within Multinational Corporations, Strategic Management Journal, 21(4): 473-496.

Hannan, M. T. i Freeman, J. (1977.), The population ecology of organizations, American Journal of Sociology, 82(5): 929-964.

Hedlund, G. (1986.), The hypermodern MNC-A heterarchy? Human Resource Management, 25(1): 9-35.

Hymer, S. (1960.), On multinational corporations and foreign direct investment. The Theory of Transnational Corporations, Routledge, London

Jarillo, J. C. i Martíanez, J. I. (1990.), Different roles for subsidiaries: the case of multinational corporations in Spain, Strategic Management Journal, 11(7): 501-512.

Kogut, B. i Singh, H. (1988.), The effect of national culture on the choice of entry mode, Journal of International Business Studies, 19(3): 411-432.

Kogut, B. i Zander, U. (1992.), Knowledge of the firm, combinative capabilities, and the replication of technology, Organization science, 3(3): 383-397.

Kovač, M. (2017) Utjecaj strateških inicijativa međunarodnih podružnica na matično poduzeće u industriji informacijsko-komunikacijske tehnologije. Doktorski rad. Ekonomski fakultet, Zagreb.

Lilienthal, D. (1960.), The Multinational Corporation, u: Ashen, M. i Bach, G. (eds.), Management and Corporations, McGraw-Hill, New York, 197-219.

Montealegre, R. (2002.), A process model of capability development: Lessons from the electronic commerce strategy at Bolsa de Valores de Guayaquil, Organization science, 13(5): 514-531.

Pahlberg, C. (1996.), Subsidiary-Headquarters Relationships in International Business Networks, Uppsala University, Uppsala

Paterson, S. L. i Brock, D. M. (2002.), The development of subsidiary-management research: review and theoretical analysis, International Business Review, 11(2): 139-163.

Pearce, R. D. (1992.), World product mandates and MNE specialization, Scandinavian International Business Review, 1(2): 38-58. 
Prahalad, C. K. i Doz, Y. L. (1981.), An approach to strategic control in MNCs, Sloan Management Review, 22(4): 5-13.

Rahimić, Z. i Podrug, N. (2013.), Međunarodni menadžment, Ekonomski fakultet u Sarajevu, Sarajevo

Roth, K. i Morrison, A. J. (1992.), Implementing global strategies: Characteristics of global subsidiary mandates, Journal of International Business Studies, 23(4): 715-735.

Rugman, A. M. (2002.), International business: critical perspectives on business and management, Routledge, New York

Taggart, J. (1997.), Autonomy and Procedural Justice: A Framework for Evaluating Subsidiary Strategy, Journal of International Business Studies, 28(1): 51-76.

Taggart, J. H. (1998.), Strategy Shifts in MNC Subsidiaries, Strategic Management Journal, 19(7): 663-681.

Teece, D. J. (2010.), Business models, business strategy and innovation, Long range planning, 43(2): 172-194.

Teece, D. J., Pisano, G. i Shuen, A. (1997.), Dynamic capabilities and strategic management, Strategic Management Journal, 18(7): 509-533.

UNCTAD (2017.), World Investment Report 2017, http:/unctad.org/en/Pages/ DIAE/ World\%20Investment\%20Report/Annex-Tables.aspx, pristupljeno: 20.09.2018.

Vernon, R. (1966.), International investment and international trade in the product life cycle, Quarterly Journal of Economics, 80(2): 190-207.

Weerawardena, J., Mort, G. S., Liesch, P. W. i Knight, G. (2007.), Conceptualizing accelerated internationalization in the born global firm: A dynamic capabilities perspective, Journal of World Business, 42(3): 294-306.

Westney, D. E. (1993.), Organization theory and the multinational corporation, Palgrave Macmillan, UK

White, R. E. i Poynter, T. A. (1984.), Strategies for foreign-owned subsidiaries in Canada, Business Quarterly, 49(2): 59-69.

Young, S., Hood, N. i Peters, E. (1994.), Multinational enterprises and regional economic development, Regional studies, 28(7): 657-677. 


\title{
PARTICULARS OF STRATEGIC MANAGEMENT IN INTERNATIONAL SUBSIDIARIES
}

\author{
Summary
}

As an international company is a group of geographically dispersed international subsidiaries, each of which has its own goals and requests related to development, it is logical to introduce the need to study the particulars of strategic management in international subsidiaries. The paper presents conceptualization and evolution of international companies and international subsidiaries. The roles of international subsidiaries have been analyzed separately. Literature confirms that international subsidiaries have particular roles they play within an international company, and the interaction between the parent company and international subsidiaries and the influence of the local market on the operations of international subsidiaries are crucial in defining their roles and responsibilities. Of all identified variables, integrity and autonomy are largely present in almost all types of roles. The management of international subsidiaries also includes the development of international subsidiaries that can be observed towards the parent company, but also in the country where an international subsidiary is located. In the conclusion of the paper, the specificities of the relationship between the parent company and international subsidiaries are emphasized as a relevant segment of strategic management in international subsidiaries.

Key words: international company, parent company, international subsidiary, strategic management 